\title{
Policy Issues Surrounding Processes of Centralization and Decentralization in European Education Systems
}

\author{
H.W.C. Gonnie van Amelsvoort and Jaap Scheerens \\ Faculty of Educational Science and Technology, University of Twente
}

\begin{abstract}
Four levels of authority within the educational decision-making structure in seven European countries and states for primary and lower secondary education are analyzed. Next, the results of an investigation on loci, domains and modes of decision making are presented, indicating a slightly higher degree of school autonomy in England/Wales, the Netherlands and Sweden than in the other countries and states. A more evaluative assessment shows that democratization, market orientation, recession and general aims of improving the quality and equality of education are important background forces in shifting patterns of centralization and decentralization in the investigated countries and states.
\end{abstract}

\section{INTRODUCTION}

In recent years there has been a tendency towards decentralization and deregulation in European societies. These processes can also be witnessed in the field of education. As international developments and experiences are increasingly taken into account when developing national policies, a comparative study on the actual situation and intended developments in seven European countries and states was conducted as a project contracted by the Dutch Ministry of Education.

The conceptual basis for the study was a three-dimensional framework which distinguished levels, domains and modes of decision making, and a set of evaluative criteria to appraise the evolving patterns in decisionmaking structures in the seven countries. The following criteria were

Correspondence: H.W.C. Gonnie van Amelsvoort, University of Twente, Faculty of Educational Science and Technology, Department of Educational Organization and Management, PO Box 217, 7500 AE Enschede, the Netherlands.

Manuscript submitted: June 20, 1996

Accepted for publication: April 29, 1997 
considered: (1) efficiency in terms of budget control; (2) greater responsiveness and less bureaucratization; (3) the quality of education in terms of improved performance and accountability; (4) professionalization of schools in terms of creative human resources management, potential for innovation and responsiveness to local communities; (5) equity; and (6) optimal scale (i.e., school size).

Next to the description of the developments that are taking place in the administration and management of some European education systems, the study aimed to explore the usefulness and appropriateness of current research methods and instruments in order to further the comparison of international education systems in the future.

\section{CONCEPTUAL BASIS}

\section{A Three Dimensional Classification of Decision-Making Patterns}

The pragmatic aim in the design of the study was to conceptualize patterns of centralization and decentralization in a sufficiently refined, yet concise manner. On the basis of a review of the relevant literature, and discussions in an international forum (delegates of 17 countries to the project of the Organization for Economic Co-operation and Development on Education Indicators - the INES project) three facets of the rather crude distinction between centralization and decentralization were considered:

(1) the tier or administrative level where a decision is taken; this dimension was referred to as the locus of decision-making;

(2) the amount of discretion, or the degree of autonomy of decisionmaking at a particular administrative level; this facet was called the mode of decision-making;

(3) the particular element of educational administration a decision belonged to; this facet was referred to as the domain of decision-making.

These three facets can be related to existing categorizations in the relevant literature, although the use of central concepts is by no means consistent among authors and publications. Our three-dimensional conceptualization is compared to the terminology as clarified by Bray (1994, p. 819) in an analysis of alternative meanings of centralization and decentralization.

The distinction between levels conforms to the concept of territorial decentralization, defined as "the distribution of powers between different tiers of government". In the operationalization of this dimension we dis- 
tinguished four tiers, to be further described in the section on methods.

Degrees of autonomy in decision making at a particular level are reflected in terms that refer to an increase in discretion. Again following Bray, deconcentration, delegation and devolution are modes of decision making in which an increased amount of decision-making authority resides at a lower level.

Deconcentration is the process through which a central authority establishes field units, staffing them with its own officers.(...) Delegation implies a stronger degree of decision making at the lower level. However, powers in a delegated system still basically rest with the central authority, which has chosen to "lend" them to a local one.(...) Devolution is the most extreme form of decentralization. Powers are formally held by local bodies, which do not need to seek approval for their actions (Bray, p. 819).

In our operationalization of this continuum of increasing autonomy, these abstract definitions were avoided and respondents were asked to indicate whether decisions could be taken within the framework determined by a higher level, in consultation with a higher level or in full autonomy.

In order to determine elements or domains of educational administration, many categorization schemes are available in the literature (e.g., Bacharach, Bamberger, Conley, \& Bauer, 1990; James, 1994; Rideout \& Ural, 1993; Winkler, 1989). The common core of these categorizations are three main areas:

(1) an educational domain (goals, methods, curricula, evaluation procedures);

(2) an organizational, managerial and administrative domain (including human resource management, groupings and assignment and foundational regulations);

(3) a dimension concerning finance and the way financial resources are applied.

In the operational classification that we chose four main categories were used, by splitting up area 2 (organizational) into two domains "planning structures" and "human resources", and including areas 1 and 3.

The distinction between domains of decision-making in educational systems bears some resemblance to Bray's use of the term "functional decentralization" as cited from Rondinelli. "Functional decentralization refers to the dispersal of control over particular activities" (Bray, 1994, p. 819). From the examples that he provides, however, it is not clear 
whether in functional decentralization an exhaustive set of domains of educational decision-making is referred to, as is the purpose of the categorization schemes cited above. The common denominator is the recognition that educational systems may be centralized in some domains of decision-making but not in others. Our conclusion is therefore that in a somewhat liberal use of the term our distinction between domains of educational decision-making can be considered as a form of functional decentralization.

\section{Common Policy Aims in Current Shifts in Decision-making Struc- tures}

As noted in the introduction there are decentralization tendencies in educational restructuring policies in many industrialized countries. At the same time decentralization appears to be partial or "functional", since in some countries decentralization in, for example, the financial domain, is accompanied by centralization in another domain, for example the curricular domain. There appear to be common aspirations behind these restructuring tendencies, which, for our purposes, can be used to enable a more evaluative review of these developments. The following aims will be considered as criteria for appraisal: budget control, less "red tape", responsiveness to local communities, creative human resource management and innovation, accountability, quality, equity, and optimal scale.

\section{Budget Control}

In many industrialized countries retrenchment policies with respect to the public sector are pursued. One way of keeping central expenditure on education under control is to give more responsibility to lower administrative levels, in particular school-boards and schools, to ensure they keep within the limits of the budget. Some scholars (e.g., Hargreaves, 1991) have mockingly described this as the "devolution of blame". Gains in efficiency in these cases should not merely be seen as a result of passing down responsibilities but also as a result of budget setting and stricter budget monitoring initiated at the central level. It is interesting to register to what extent restructuring is indeed taking place in order to enhance cost-effectiveness in education, as stated in the official policy, and to what degree this objective is actually being reached.

\section{Less Red Tape}

According to Crowson and Morris (1985) elementary school leaders in a Chicago school district spent no less than 36 per cent of their working 
time on dealing with regulations and official requirements. Their colleagues at the secondary level needed 47 per cent of their working time for these activities. "Lump sum" financing of schools is an example of deregulation in the area of financial resources management.

Instead of having to account for each and every purchase, schools just have to manage to do their job within the limits of the overall school budget. (Of course this deregulation effect becomes strongly diminished if schools have to provide very detailed information to the government to enable it to fix the level of lump sum!) A phenomenon that has been observed in other sectors of society is that when deregulation and devolution of authority is practiced by the national government, an intermediary level body may step in and take over the formal regulative activities, so that "red-tape" just travels from one level to the next.

Ideally, deregulation would free time and energy for school managers, which they then could spend on activities that are thought to be instrumental to quality and responsiveness. On the other hand, as in the example of lump sum financing, school managers are given additional responsibilities in the area of resources management time that thus will not be available for instructional leadership.

To summarize, one could say that "debureaucratization" can be attained by the following measures:

(1) lump sum financing;

(2) a diminishing of rules and formal regulations (de-formalization);

(3) globalization of regulations, for instance by using so called "framelaws";

(4) simplification of the decision-making structure by abolishing a particular decision-making level.

When using the phrase diminishing of "red tape", the associated organizational inefficiency of strongly regulated administrative control is referred to. A diminishing of regulations, accompanied by changes in the incentive structures by means of the stimulation of market mechanism, is usually seen as a way of creating more efficiency. This approach is evident in applications of public choice theory.

The empirical evidence on the efficiency gains reached by these alternative forms of educational finance and control is not convincing, however. Riddell, for example, concludes that there is no overwhelming evidence regarding the greater efficiency and effectiveness of private, relative to public schools (Riddell, 1993). 


\section{Responsiveness to Local Communities}

To the degree that schools are less the object of control by a higher administrative level there will be more opportunities to adapt school policies to the demands of the local situation. In primary and secondary schools parents, who could be regarded as responsible for the "consumers" of education, are the most important demanding party. In vocational education local industry could also be seen as fulfilling this role.

The most straightforward plea for school autonomy and freedom of choice is made by Chubb and Moe (1990), who also present empirical evidence, which, they claim, show that autonomy enhances school effectiveness. The validity of their conclusions based on secondary analysis of the High School and Beyond data set are contested, however (Scheerens, 1995; Witte, 1990). The treatment of the advantages and disadvantages of choice of schools in the OECD report, titled "School: a matter of choice" (OECD, 1994) shows more nuances. According to this report, autonomy could only be expected to enhance school effectiveness indirectly, namely to the degree that competition is likely to stimulate schools to develop strong leadership, a sense of mission and more parent involvement. At the same time "choice" is bound to enlarge inequalities in education, also in the sense that autonomy of schools will make it more difficult to monitor system-wide educational policies concerning performance standards.

Lack of control with respect to curriculum goals and standards for primary and secondary schools is also the major disadvantage that Leune (1994) sees with respect to autonomy in the area of the primary process of education. He sees common standards as a prerequisite for quality control and co-ordination between levels of schooling (primary and secondary).

In many education systems, deregulation and decentralization towards more autonomous schools is a rather partial affair in which more autonomy in certain domains is paired with more centralized control in other areas. What effects are likely to follow from such mixed policies is an interesting issue for debate and empirical research. Would it be possible, for instance, to increase parental influence and choice, while at the same time implementing a national curriculum? Also, it should be noted that the balance between centralized control and school autonomy is likely to be valued differently for different educational levels (primary, secondary, vocational and higher education).

\section{Creative Human Resource Management and Innovation}

The existence of national standards of minimum quality, with consequences for both the effectiveness and equity of the system, is not generally considered as a controversial point. Aspects like salary levels, oppor- 
tunities for promotion, hiring and firing of teachers, and teacher appraisal are more often contested. To the degree that schools are part of the public administration, these aspects are generally highly regulated. Regulations in this area are also likely to be scrutinized and defended by teacher unions. However, considering the vital importance of teacher quality for school effectiveness (see, e.g., Luyten \& Snijders, 1995; OECD, 1994), some people expect that more managerial control in this area would give schools more leverage in improving performance. Task differentiation and increased career options for teachers are also considered important to keep teachers' motivation going and prevent "burn out".

Schools perceived as "professional bureaucracies" are depicted as very conservative, "hard to change" organizations (Mintzberg, 1979). Providing schools with more autonomy and stimulating "self-management" could be seen as a way to make them more innovative. Depending on the particular emphasis given to certain domains when functional decentralization takes place, there will be appeals to be innovative in various aspects of school functioning. One hypothesis, for instance, could be that a lot of the innovation capacity of schools will be concentrated in the areas of financial management, when it is particularly in this area that deregulation and decentralization of authority take place, while there would be virtually no innovation with respect to the primary process of teaching and learning (Scheerens, 1993).

\section{Accountability}

Particularly when devolution policies take the shape of "freeing processes" while at the same time sharpening output control, accountability is an important and probably controversial aspect of these policies. Chubb and Moe (1990) are adamant in pointing out that accountability requirements cannot be reconciled and are in fact detrimental to the ideals of choice and market control. It is an interesting question for empirical research to investigate how combinations like this work out in practice, and to what extent ideals of greater school autonomy can still be meaningful, even though the primary process of education is centrally controlled through national curriculum frameworks, standards and assessment programmes. Specific foci of attention should be the "bureaucratic" side-effects of accountability regulations as well as the political reactions of schools when the stakes of "looking good" on performance assessments are high (cf. Beaton, 1992).

Of course the accountability issue is a complex issue with many facets. Macpherson (1995), for example, draws attention to counter-productive "political" effects of high-stakes assessments, a lack of fit between ac- 
countability processes and criteria on the one hand and reform policies on the other, and the question to what extent accountability in itself should be centralized or decentralized. Despite the complexity of the issue and the divergence in applications he concludes that "there is a great deal of evidence accumulating that indicates that basic standards of public accountability need to be evident, in open and fair processes, by explicit criteria being used in decision making and documentation, and by those who make decisions being held accountable for them" (Macpherson, 1995, p. 566).

\section{Quality}

Two opposing hypotheses can be formulated with respect to the expected impact of increased autonomy of schools on average performance:

(1) autonomy will lead to improved performance through mechanisms like a clear mission, more pronounced leadership and greater parental involvement;

(2) autonomy, particularly with respect to curriculum and instruction, will, on average, lead to lower performance, due to the lack of a common educational core and monitoring of national standards; also autonomy could make the coordination between educational levels (e.g., primary and secondary) more difficult which could also lead to lower overall performance.

Mixed policies (free processes, monitor outcomes) might be seen as trying to have the best of both worlds, although here the question arises to what extent such policies are successfully and harmoniously being implemented, rather than one perspective dominating the other.

\section{Equity}

With respect to the devolution of authority to schools the ideal of greater responsiveness of autonomous schools can be extended to the notion of being responsive to the special needs of pupils (Crump, 1994), including the special needs of "low income, minority, single-parent and other excluded groups".

On the other hand, one might fear that choice and autonomy would actually enlarge inequalities because schools might become stimulated to select a high intake of more advantaged pupils, whereas middle-class parents could be expected to make better use of information provided to schools than lower-class parents (Scheerens, Korevaar, \& De Rijcke, 1991). In fact this latter contention is supported by empirical evidence from the UK. Gerwitz, Bowe, and Ball (1994) report the following findings: 
(1) The market is a middle-class mode of social engagement.

(2) Parental choice of schools is class- and race-informed.

(3) Schools are increasingly oriented towards meeting the perceived demands of middle-class parents.

(4) The cumulative impact of findings $1-3$ is the "decomprehensivization" of secondary schooling.

Apparently, without specific compensatory incentives provided from some central source, calculating parents and calculating schools will jointly work towards a more segregated system when schools have to operate as competing firms.

\section{Optimal Scale}

More choice and autonomy in schooling could be expected to give rise to smaller, specialized units. On the other hand, a certain scale might be considered necessary to provide a diversified set of curricular offerings in a way that can still be efficient. Also, it is sometimes maintained that schools need a certain scale to be able to function as responsive, professional organizations. It is interesting to evaluate and see how different education systems combine or do not combine policies with respect to increased autonomy and increased size of schools.

\section{METHODS}

In view of the Dutch policy to cooperate in education with the neighbouring states of Flanders (FLA), North-Rhine Westphalia (NOW) and Lower Saxony (LOS), these three states were selected for the study. In addition England/Wales (ENG), Sweden (SWE) and Portugal (POR) were selected as countries in which different priorities are given to shifts in functional decentralization. The instrumentation of this study encompassed three methods: (1) literature search; (2) data collection by means of a questionnaire; and (3) a semi-structured interview.

A first image of the existing decision-making structure was drawn up based on information that emerged from a literature search on existing international education systems. This description was submitted to the respondents and updated by them.

The factual basis for functional decentralization within the selected countries or states was assessed by means of the instrument developed in the OECD-CERI-INES-project. Basically the instrument consists of a three-dimensional grid, the dimensions being: 
(1) domains of decision making (four main domains are considered: "organization of instruction", "curriculum/planning structures", "personnel management" and "resources", each domain is represented by 7-12 items;

(2) levels of decision making (four levels are distinguished: the school, a first intermediary level that is closest to the school, a second intermediary level that is closest to the central government and the central level);

(3) modes of decision making (three modes are identified): full autonomy at a certain level; jointly or in consultation with another level; and freely, but within a framework decided at a more central level).

Data from this "locus of the decision-making" questionnaire were analyzed by summing "scores" per domain and by weighting the domain scores by the number of items before comparing the relative importance of loci and modes of decision making. This means that 25 per cent is allocated to the four domains, equally divided between each of the items making up the domain. So, the weight of a single item depends on the number of items included in the domain to which it belongs. When an item did not appear to be meaningful for a particular situation (e.g., in Sweden no decisions with respect to examinations are taken at both ISCED levels ${ }^{1}$ ) the weights of the other decisions within the domain were adjusted.

In order to get an impression of the dynamics concerning functional decentralization in each country/state and also to make an inventory of the perspectives with respect to the related policy issues, a semi-structured interview was administered to two or three respondents per country/state. These couples consisted in most cases of a policy-planning officer from a government department and one or two external educational experts.

The main topics for the semi-structured interviews were:

(1) major changes that may have taken place in the educational decisionmaking structure over the last five years;

(2) the major motives/goals of educational policies concerning functional centralization and decentralization, in terms of quality enhancement, efficiency, equity, more professional schools, responsiveness of education, and less red tape;

(3) indications of the effects of these policies in relation to their goals;

(4) indications of side-effects of policies in terms of shifting red tape, loosening of standards, poor vertical coordination of curricula, ne-

${ }^{1}$ ISCED = International Standard Classification of Education, ISCED level 1 is the primary level, ISCED level 2 is the lower stage of secondary education. 
glect of primary process in comparison to attention for management and organization, and a more elitist system;

(5) the degree to which policies related to the above issues are geared to policy measures with respect to scale.

\section{RESULTS}

\section{Levels of Authority}

Table 1 gives an overview of the levels of authority in each of the seven countries or states that existed at the time of the study. These levels have been specified as follows: (1) school level. This level includes any decision maker at school level, including teachers, head teachers and parents; (2) lower intermediate level. The level of decision making closest to the school, usually the local authority. It may be a municipal authority with other responsibilities or an authority that is only responsible for education. In the latter case, the authority may consist of a 'school-board'; (3) upper intermediate level. The level closest to the central government. This may be a regional agency of the central government or a regional level that is distinct from the central government; (4) central government. The decision making level furthest removed from the school.

\section{Loci, Domains and Modes of Decision Making}

It is important to notice that any results regarding the degree of functional and territorial decentralization are dependent on the list of items that were selected for inclusion in each domain category and must be interpreted within this context. Furthermore, all results are valid for the sample only. The results given here apply to the public sector of primary (ISCED 1) and lower secondary education (ISCED 2). Results for primary and lower secondary education were taken together because there appeared to be hardly any differences between countries with respect to the locus and mode of decision making at these education levels with the exception of Portugal where relatively more decisions at ISCED 1 are taken at school level and the lower intermediate level, whereas relatively more decisions at ISCED 2 are taken at higher authority levels.

For Portugal and Sweden, the countries in which data were obtained in 1992, the current state of affairs in 1995 was compared with the outcomes of 1992. Available figures for 1992 are reported in the tables in parentheses. It should be noted that these comparisons should be regarded with caution because the data could not be obtained in a completely identical research situation. 
Table 1. Educational Authority Levels for Public Primary and Lower Secondary Education.

\begin{tabular}{|c|c|c|c|c|}
\hline \multicolumn{2}{|l|}{ School level } & \multirow{2}{*}{$\frac{\text { Lower intermediate level }}{\text { Local Education Authority }}$} & \multirow{2}{*}{$\begin{array}{l}\text { Upper intermediate level } \\
\text { (School Examinations and } \\
\text { Assessment Council) }\end{array}$} & \multirow{2}{*}{$\frac{\text { Central }}{\text { England/Wales }}$} \\
\hline $\begin{array}{l}\text { Primary } \\
\text { education }\end{array}$ & $\begin{array}{l}\text { England }^{1} \\
\text { Wales }\end{array}$ & & & \\
\hline & Flanders & $\begin{array}{l}\text { Organizing body: } \\
\text { ARGO / Inrichtende macht }\end{array}$ & - & $\begin{array}{l}\text { - Community: Flanders } \\
\text { - Belgium }\end{array}$ \\
\hline & $\begin{array}{l}\text { Lower } \\
\text { Saxony }\end{array}$ & $\begin{array}{l}\text { - Municipality: Gemeinde/ } \\
\text { Landkreis } \\
\text { - Governing body: Schul- } \\
\text { aufsichtamt }\end{array}$ & Region: Bezirksregierung & $\begin{array}{l}\text { - State: Lower Saxony } \\
\text { - Germany }\end{array}$ \\
\hline & Netherlands & $\begin{array}{l}\text { - Municipality as governing } \\
\text { authority (school-board) for } \\
\text { publicly-run schools: } \\
\text { Gemeente als schoolbestuur }\end{array}$ & $\begin{array}{l}\text { - Municipality as local } \\
\text { authority: Gemeente als } \\
\text { lokale overheid } \\
\text { - (Province) }\end{array}$ & the Netherlands \\
\hline & $\begin{array}{l}\text { North Rhine } \\
\text { Westphalia }\end{array}$ & $\begin{array}{l}\text { - Municipality: Gemeinde } \\
\text { - Governing body: Schulamt }\end{array}$ & Region: Bezirksregierung & $\begin{array}{l}\text { - State: North Rhine } \\
\text { Westphalia } \\
\text { - Germany }\end{array}$ \\
\hline & Portugal $^{5}$ & Municipality: Autarquia & $\begin{array}{l}\text { Regional Directorates of } \\
\text { Education: } \\
\text { Dir. Regional de Educação }\end{array}$ & Portugal \\
\hline & Sweden & $\begin{array}{l}\text { Municipality: Kommun } \\
\text { Local Education Authority }\end{array}$ & - & Sweden \\
\hline
\end{tabular}




\begin{tabular}{|c|c|c|c|c|}
\hline School level & & Lower intermediate level & Upper intermediate level & Central \\
\hline \multirow[t]{7}{*}{$\begin{array}{l}\text { Secondary } \\
\text { education }\end{array}$} & $\begin{array}{l}\text { England } /^{1} \\
\text { Wales }\end{array}$ & Local Education Authority & $\begin{array}{l}\text { (School Examinations and } \\
\text { Assessment Council) }\end{array}$ & England/Wales \\
\hline & Flanders $^{2}$ & $\begin{array}{l}\text { Organizing body: } \\
\text { ARGO / Inrichtende macht }\end{array}$ & - & $\begin{array}{l}\text { - Community: Flanders } \\
\text { - Belgium }\end{array}$ \\
\hline & Lower Saxony & $\begin{array}{l}\text { - Municipality: Gemeinde/ } \\
\text { Landkreis } \\
\text { - Governing body: } \\
\text { Schulaufsichtsamt } \\
\text { Sh }^{3}\end{array}$ & Region: Bezirksregierung & $\begin{array}{l}\text { - State: Lower Saxony } \\
\text { - Germany }\end{array}$ \\
\hline & Netherlands & $\begin{array}{l}\text { - Municipality as governing } \\
\text { authority (school-board) for } \\
\text { publicly-run schools: } \\
\text { Gemeente als schoolbestuur }\end{array}$ & $\begin{array}{l}\text { - Municipality as local } \\
\text { authority: Gemeente als } \\
\text { lokale overheid } \\
\text { - (Province) }\end{array}$ & the Netherlands \\
\hline & $\begin{array}{l}\text { North Rhine } \\
\text { Westphalia }\end{array}$ & $\begin{array}{l}\text { - Municipality: Gemeinde } \\
\text { - Governing body: Schulamt }\end{array}$ & Region: Bezirksregierung & $\begin{array}{l}\text { - State: North Rhine } \\
\text { Westphalia } \\
\text { - Germany }\end{array}$ \\
\hline & Portugal $^{5}$ & $\begin{array}{l}\text { (Centres for educational support, } \\
\text { CAE) }\end{array}$ & $\begin{array}{l}\text { Regional Directorates of } \\
\text { Education: } \\
\text { Dir. Regional de Educação }\end{array}$ & Portugal \\
\hline & Sweden & $\begin{array}{l}\text { Municipality: Kommun } \\
\text { Local Education Authority }\end{array}$ & - & Sweden \\
\hline
\end{tabular}

1 Governing board included in school level.

2 Local school councils included in school level.

3 Only for Hauptschule, Orientierungsstufe, Realschule, Sonderschule.

4 Only for Hauptschule, Orientierungsstufe, Realschule.

5 Management bodies like the School (Area) Council, the Pedagogical Council and the Administrative Council included in the school level. 
Table 2 shows the percentage of educational decisions taken at the four specified levels. For example, in England/Wales 64 per cent of all the educational decisions are taken at school level. Decisions taken at the four levels only include primary decision makers and do not include a measure of whether other authorities are being consulted during the decision-making process or whether decisions are taken within a framework stipulated by another decision-making level. As a consequence, the figures should not be interpreted as an estimate of the total role the levels play in the decision-making process.

Depending on one's perspective, one would not only be interested in how many decisions are taken at various levels but also in which domain they are taken.

Table 3 shows the decisions taken at each level divided over decision domains as a percentage of all decisions. As all four domains have been

Table 2. Percentage of All Decisions Taken by Level of Governance, ISCED 1 and 2 Public Education.

\begin{tabular}{llccc}
\hline & \multicolumn{4}{c}{ Locus of decision making } \\
\cline { 2 - 5 } Country /State & School & Level 1 & Level 2 & Central \\
\hline England/Wales & 64 & 21 & $6^{1}$ & 9 \\
Flanders & 31 & 40 & - & 29 \\
Lower Saxony & 29 & 17 & $28^{2}$ & 26 \\
Netherlands & $54^{3}$ & 20 & $5^{4}$ & 21 \\
North Rhine Westphalia & 29 & 33 & 9 & 30 \\
Portugal & $32(42)$ & $9(-)$ & $2(3)$ & $56(55)$ \\
Sweden & $51(47)$ & $35(47)$ & $-(-)$ & $15(6)$ \\
\hline
\end{tabular}

Note. Figures for 1992 within parentheses.

1 This figure refers to decisions on credentialling which are taken by the School Examinations and Assessment Council.

2 Decisions on allocation of resources to schools for teaching staff are included in this figure. Actually, they are shared between the upper intermediate and central level. The number of posts which are allocated in the budget is a decision taken by parliament (prepared by the government). The distribution of the vacant posts to the four administrative districts of Lower Saxony is done by the ministry. The hiring of teachers and the allocation of teachers to schools is decided by the government of the administrative districts (= Bezirksregierungen).

3 Note that the figure for the Netherlands at school level includes decisions for which the governing body is formally responsible but that in practice have been delegated to schools.

4 The upper intermediate level can add money to the national resources, bound to the central regulations dealing with equal treatment of private and public schools. Resource allocation for capital expenditure in the case of primary education schools is partly being decentralized from central government to upper intermediate level. 
given an equal weight of 25 per cent, only 25 per cent per domain can be divided over the four levels. For example, the figure 25 for England/ Wales in the first column refers to the organization of instruction decisions taken at school level. This means that in England and Wales all decisions in the organization of instruction domain are taken at school level.

Table 4 shows decisions at the various governance levels as a percentage of all decisions, broken down by the three specified modes of decision making: autonomously, through consultation with another level and within a framework stipulated by a higher level. For example, 39 per cent of all decisions in England/Wales are taken by schools in full autonomy.

In the above factual information on territorial decentralization has been provided by a description of the loci (school, lower intermediate, upper intermediate, central) and the modes (autonomously, jointly or after consultation, within a framework) of decision making. Information on functional decentralization has been linked to the domains (organization of instruction, personnel management, curriculum (planning and structures),

Table 3. Percentage of All Decisions in Four Domains of Decision-Making per Level, ISCED 1 and 2 Public Education.

\begin{tabular}{|c|c|c|c|c|c|c|c|c|c|c|c|c|c|c|c|c|c|}
\hline \multirow[b]{3}{*}{ Country/State } & \multicolumn{16}{|c|}{ Decisions taken by level of governance ${ }^{a}$} & \multirow{3}{*}{ Total $^{b}$} \\
\hline & \multicolumn{4}{|c|}{ School } & \multicolumn{4}{|c|}{ Level 1} & \multicolumn{4}{|c|}{ Level 2} & \multicolumn{4}{|c|}{ Central } & \\
\hline & 1 & 2 & 3 & 4 & 1 & 2 & 3 & $\overline{4}$ & 1 & 2 & 3 & 4 & 1 & 2 & 3 & $\overline{4}$ & \\
\hline ngland/ & & & & & & & & & & & & & & & & & \\
\hline Wales & 25 & 25 & 3 & 11 & - & - & 6 & 14 & - & - & 6 & - & - & - & 9 & - & 99 \\
\hline Flanders & 22 & - & 9 & - & - & 17 & 13 & 11 & - & - & - & - & 3 & 8 & 3 & 14 & 100 \\
\hline Lower Saxony & 22 & - & 3 & 4 & - & - & 3 & 14 & - & 15 & 6 & 7 & 3 & 10 & 13 & - & 100 \\
\hline Netherlands & 25 & 6 & 15 & 7 & - & 12 & 4 & 4 & - & - & - & 5 & - & 6 & 6 & 9 & 99 \\
\hline $\begin{array}{l}\text { North Rhine } \\
\text { Westphalia }\end{array}$ & 22 & - & 7 & - & - & 8 & 3 & 21 & - & 5 & - & 4 & 3 & 11 & 15 & - & 99 \\
\hline Portugal & $\begin{array}{l}19 \\
(19)(\end{array}$ & $\begin{array}{c}8 \\
(10)\end{array}$ & $\frac{-}{(6)}$ & $\begin{array}{l}5 \\
(7)\end{array}$ & - & 2 & - & 7 & - & 2 & - & - & 6 & 12 & 25 & 13 & 99 \\
\hline Sweden & $\begin{array}{c}25 \\
(22)\end{array}$ & $\begin{array}{l}15 \\
(8)\end{array}$ & $\begin{array}{c}4 \\
(9)\end{array}$ & $\begin{array}{c}7 \\
(7)\end{array}$ & - & 8 & 8 & 18 & - & - & - & - & - & 2 & 13 & - & 100 \\
\hline
\end{tabular}

Note. Figures for 1992 within parentheses.

1 = organization of instruction; 2 = personnel management; 3 = curriculum (planning and structures); 4 = resources.

a The figures per level (per country) add up to the total (per country) given in Table 2.

b Totals may not add up to 100 per cent due to rounding. 
Table 4. Percentage of Modes of Decision making per Level, ISCED 1 and 2 Public Education.

\begin{tabular}{|c|c|c|c|c|c|c|c|c|c|c|c|c|c|c|c|c|}
\hline \multirow[b]{3}{*}{ Country/State } & \multicolumn{16}{|c|}{ Decisions taken by level of governance ${ }^{a}$} \\
\hline & \multicolumn{4}{|c|}{ School } & \multicolumn{4}{|c|}{ Level 1} & \multicolumn{4}{|c|}{ Level 2} & \multicolumn{4}{|c|}{ Central } \\
\hline & 1 & 2 & 3 & 4 & 1 & 2 & 3 & 4 & 1 & 2 & 3 & 4 & 1 & 2 & 3 & 4 \\
\hline \multicolumn{17}{|l|}{ England/ } \\
\hline Wales & 39 & - & 25 & - & - & - & $21^{\mathrm{b}}$ & - & & - & 6 & - & 9 & - & - & - \\
\hline Flanders & 25 & - & 6 & - & 11 & - & 29 & - & - & - & - & - & 29 & - & - & - \\
\hline Lower Saxony & 4 & - & 25 & - & 11 & 4 & 3 & - & 8 & 12 & 9 & - & 26 & - & - & - \\
\hline Netherlands & 24 & 7 & 22 & - & 10 & 4 & 6 & - & - & - & 5 & - & 9 & - & - & $12^{c}$ \\
\hline $\begin{array}{l}\text { North Rhine } \\
\text { Westphalia }\end{array}$ & 8 & - & 21 & - & 26 & 3 & 4 & - & 4 & 1 & 4 & - & 28 & 1 & - & - \\
\hline Portugal & $\begin{array}{l}11 \\
(9)\end{array}$ & $\begin{array}{c}2 \\
(2)\end{array}$ & $\begin{array}{l}19 \\
(31)\end{array}$ & - & 7 & 2 & - & - & - & - & 2 & - & $\begin{array}{c}24 \\
(52)\end{array}$ & $\begin{array}{l}12 \\
\text { (3) }\end{array}$ & - & $21^{\mathrm{c}}$ \\
\hline Sweden & $\begin{array}{c}14 \\
(15)\end{array}$ & $\begin{array}{l}10 \\
(-)\end{array}$ & $\begin{array}{c}27 \\
(32)\end{array}$ & - & 26 & 2 & 6 & - & - & - & - & - & $\begin{array}{l}13 \\
(6)\end{array}$ & $\begin{array}{l}- \\
(-)\end{array}$ & - & 2 \\
\hline
\end{tabular}

Note. Figures for 1992 within parentheses.

$1=$ in full autonomy; $2=$ jointly or in consultation with another level; $3=$ within a framework set by a higher authority; $4=$ other.

a The figures per level (per country) add up to the total (per country) given in Table 2.

b In England/Wales decisions on creation, closure or abolition of schools and grade levels are taken within a framework set by the central government but in addition schools are consulted.

c 'Other' in the Netherlands and Portugal refers to consultation with all the authority levels and negotiations with the unions.

resources) of decision making. The summary below will be focused at the school level and the degree of school autonomy.

A first indication of school autonomy can be given just by looking at the number of decisions taken at a particular level. Based on this criterion it appears that in England/Wales, the Netherlands and Sweden more than 50 per cent of the decisions are taken at school level, while this is about 30 per cent in the other countries or states. In Portugal more than 50 per cent of the decisions are taken at central level.

When also taking into account the mode of decision making, that is the degree of autonomy in decision making, the results show that in England/ Wales, Flanders and the Netherlands about half of the decisions taken at school level are taken autonomously, while the other half of the number of school decisions is taken within a framework (ENG, NET). In Flanders 
nearly all school decisions are taken autonomously. In the other countries/states a substantial proportion of the decisions taken at school level is taken within a framework stipulated by a higher authority level.

The results tentatively indicate the highest degree of school autonomy in England/Wales, the Netherlands and in Sweden. A lower degree of school autonomy can be observed in the other countries/states. However, there is little variation in this degree of school autonomy.

Some critical remarks should be made in addition to this conclusion. It must be stated that the mode of decision making is not the most precise part of the assessment of the degree of territorial decentralization. Respondents were asked to indicate for the most dominant mode of decision making. Yet, it appeared that in many countries decisions are taken both in consultation and within a framework. Besides, whether a decision should be regarded as taken fully autonomously or as independently within a framework can be considered to be rather arbitrary, depending on the latitude the framework allows for.

Next to results on territorial decentralization, the results on functional decentralization can be summarized by presenting information on the domains in which the decisions are taken. It appears that decisions about the organization of instruction are the predominant type of decisions taken at school level. This is the case for all countries, independent of their level of school autonomy, as defined above. Intermediate bodies take decisions about resources, planning and structures (curriculum), and personnel management, not about the organization of instruction. Central level is either a predominant decision maker about resources (FLA, NET) or about curriculum (planning and structures) matters.

\section{Changes in Decision-Making Structures}

A more evaluative assessment of developments towards centralization and decentralization in a country/state is given in this section. As stated in the section on 'methods' this information was obtained through a semistructured interview.

One of the major forces behind the changes and developments in the decision-making structure in many countries is the tendency towards a more liberal or democratic society in which people can control their own lives (FLA, GER, NET, POR, SWE). This tendency is closely related to the more market-oriented thinking that lies behind the developments in England/Wales. In Portugal the revolution led to a reform towards democratization, with great implications for the education system. In Flanders, the establishment of the Flemish Community can be seen as an important background force, while Swedish society as a whole is in the 
middle of a major decentralization process. Recession and the need for budget control (NET, SWE) and the general aims of improving the quality and equality of education (ENG, NET) are other background forces behind centralization and decentralization processes.

Movements in the patterns of decision making have taken place in the past five years in all countries, be it that new policies were implemented or that discussions on changes in the decision-making structure took on a permanent form. Decentralization processes are still taking place in England/Wales, Flanders, the Netherlands and Sweden.

Decentralization and deregulation are subject to serious discussion in the German states. In Portugal many changes in the decision-making structure have taken place, but the restructuring process should be identified as more of a deconcentration process rather than as a decentralization process because no real devolution of powers has taken place.

In England/Wales centralization measures have been taken with respect to the curriculum. Other centralization tendencies that can be noticed concern the setting of national education objectives (NET) and the (re)introduction of national tests and examinations (ENG, NET, POR).

Deregulation, in the sense of less red tape, fewer regulations, but not accompanied by devolution of decision-making power can be observed in Flanders, the Netherlands and Sweden. These three countries have also been moving towards a more global education legislation, through socalled framework laws. This can be called a form of deregulation that is closely related to decentralization. In Portugal the deconcentration process has led to an increase in regulations.

\section{Policy Issues Surrounding Centralization and Decentralization Proc- esses}

When interpreting the policy goals and effects, it is important to bear in mind that in some countries policies are being implemented while in other countries (e.g., the German states) policies take only the form of plans or discussions.

The overall picture of our interview results showed a strong emphasis on goals like efficiency and quality enhancement. Efficiency is seen as an important goal both in terms of cost-effectiveness (ENG, FLA, LOS, NET, SWE) and in terms of debureaucratization - less red tape (LOS, SWE).

More professional schools, or responsiveness of education were mentioned less often as major goals although these issues are sometimes regarded as means to achieve quality enhancement or efficiency. 
Respondents were asked to indicate to what extent policies of deregulation and decentralization are successful with respect to the major goals mentioned.

They were also asked to mention which side-effects of current decentralization and deregulation policies they would consider "harmful" or perhaps even detrimental.

When summarizing the main evaluative statements of the respondents with respect to the goals, effects and side-effects of existing policies, variation among countries can be seen, although comparable tendencies were reported everywhere.

Quality enhancement and efficiency are the most important goals of centralization and decentralization policies or processes. In many countries the goal of enhancing the quality of education is thought to be achievable by giving schools more responsibilities, by stimulating schools to function as professional organizations, and by making schools more responsive to the needs of the local environment (parents, pupils, local policies). In some countries quality enhancement is strived for through centralization measures like the national curriculum (ENG), national education objectives (NET), setting minimum qualifications (FLA), national tests and examinations (ENG, NET, POR).

Efficiency is another important goal mentioned by the respondents. Most of the time the concept was interpreted in terms of cost-effectiveness. Cost-effectiveness either in the sense of achieving the same level of performance with a lower budget (FLA, LOS, NET, NOW, SWE), or cost-effectiveness by achieving higher standards through the same level of funding (ENG). A lower budget may be the result of budget cuts, but devoluting financial responsibility to schools is thought to be a good way to improve financial management and prevent regular budget increases. Efficiency in some countries is seen in terms of debureaucratization, not so much in the sense of less red tape, but in making the system more manageable by creating shorter lines of communication, sometimes by dispensing with a whole administrative level - which may stimulate costeffectiveness as well. Reducing regulations (less red tape) is a goal closely related to debureaucratization and often associated with changes in responsibility for decision making.

Looking at the effects and the successfulness of current centralization and decentralization policies can only be done with the utmost caution. Most respondents were hesitant to do so because it was, on the whole, too early to assess effects and some decentralization processes are still in a very early developmental stage. The overall picture shows movement in the education field. Schools are taking over responsibilities, are adapting 
to new challenges, are becoming more responsive and more professionally managed. Enhanced quality, increased efficiency or equity cannot yet be reported as policy effects.

The same caution should be maintained when looking at the possible harmful side-effects of decentralization policies. Shifts of red tape can be noticed in some countries, where another intermediary level steps in and takes over the formal regulatory activities. Some countries fear a loss of the overall responsibility for education or are worried about the system becoming more elitist. Neglect of the primary process in favour of management and organization was seen in only a few cases as an expectable side-effect of more autonomy being given to schools.

With respect to the issue of school size, it is only in the Netherlands that combined policies of increasing school size and stimulating school autonomy are actually taking place.

\section{SUMMARY AND DISCUSSION}

Deregulation takes the form of vertical decentralization in most countries, meaning that not only a reduction in regulations but also a devolution of formal decision-making authority to lower levels in the hierarchy is aimed for. Although one could speak of centralization and decentralization tendencies in the investigated countries/states, the concept is not adequate for the various processes of control and patterns of distribution of authority. In this study, associated terms like restructuring and deconcentration, which indicate change and more flexibility respectively, were used as well. Also, one should be aware of many practices of delegation of decision-making authority, which could not fully be covered by this investigation. It is important to mention the difference between formal responsibility and the way decision making is occurring in practice. For instance in Sweden and the Netherlands, where certain tasks are delegated or mandated to the schools, we see that while a higher level (i.c., the lower intermediate) is formally responsible, in practice the school decides. The formal responsibility merely takes the form of ratification or approval.

When looking at the factual situation on decision making, one could say that more than 50 per cent of all submitted decisions are taken at school level in three countries (ENG, NET, SWE). This percentage is about 30 in the other countries/states investigated. Regarding the mode of decision making at school level, it appears that decisions are taken either autonomously or within a framework. Central level decisions are mostly taken autonomously. Decisions in the domain of organization of instruc- 
tion are predominantly taken at school level, while in the domain of resources or in the domain of curriculum decisions are taken at central level.

When looking at the stage of development of current centralization and decentralization processes, one could say that the situation in the Netherlands is changing relatively fast towards decentralization in all domains, while at the same time some centralized measures are being taken to ensure the achievement of standards. In the federative structure of Germany, in which overall responsibility for education has traditionally been concentrated at state level, processes to further decentralize merely take the form of plans and discussions. In England, traditionally very decentralized with much educational decision-making power concentrated at the lower intermediate level, processes to further decentralize from the Local Education Authorities's to the school level, together with centralization in the curriculum domain can be seen, followed by some decentralizing measures with respect to curriculum modifications. In Flanders, Portugal and Sweden, policies on restructuring the decision-making structure are still in the process of implementation.

Regarding functional centralization and decentralization, according to the respondents, schools have been given more freedom to arrange the teaching process. This tendency can be observed in all countries/states, whether a national curriculum exists or not. Decentralization tendencies can also be observed in the resources domain. In many countries the finance system has become less regulated, meaning a change from very regulated and ear-marked budgets to forms of budget financing that allow for more control over the budget at school level.

The evaluative part of this study was focused on goals, effects and side-effects of current centralization and decentralization policies, as perceived by the respondents. The major goals of these policies are quality enhancement and efficiency. On the one hand quality enhancement of education is strived for by giving schools more responsibilities and stimulating them to function as professional organizations, thus making them more responsive to the needs of the environment. On the other hand centralization measures in the curriculum domain are also taken to ensure the overall quality of education. In many countries efficiency in terms of cost-effectiveness is regarded as another important goal of decentralization.

Although some movement in the field of educational responsibility can be seen, according to our respondents clear effects from centralization and decentralization policies in terms of enhanced quality, increased efficiency or equity have yet to be witnessed. 
When reflecting on the research methodology, it could be stated that the integration of the constructs of functional and territorial decentralization in the three methods used for data-collection (documentary analysis, use of the OECD-INES questionnaire on locus of decision making and semi-structured interview) has proved to be feasible, although further refinement of the instrument with respect to all three dimensions is necessary, for example a more refined distinction of levels.

Apart from this reflection on the instruments used in this study, some other methodological remarks should be made. The scope of this study was rather limited. Only information on public primary and lower secondary education could be collected, whereas especially in Flanders and in the Netherlands a large proportion of pupils attend private, government dependent schools.

Also, a relatively small number of seven countries/states could be investigated within the context of this study. Yet, the selection of countries with different priorities with respect to shifts in functional and territorial decentralization has compensated to some extent for this shortcoming.

In each country/state two or more respondents participated in the investigation, one of them being a policy maker from the department of education, the other an educational expert. It is worth bearing in mind for future research that it might be wise to interview representatives from schools too in order to avoid a certain 'policy-maker bias' in the answers. This seems particularly relevant for the evaluative part of this study in which opinions on the effects and side-effects of centralization and decentralization policies were collected. It is likely that effects of - for instance - deregulation policies are experienced differently by developers of policies than they are by the executers of these policies.

Attached to the themes of decentralization and deregulation - or more generally the shifts in patterns of centralization/decentralization in some countries - are some problems that could only be partially dealt with in our study. The equity issue requires further analytic and empirical investigation. For example, in the United Kingdom there are a number of very critical analyses of the recent reforms (e.g., Deem \& Brehony, 1994; Evans \& Lunt, 1995; Gerwitz et al., 1994) with respect to this issue. The same is true with respect to the supposed efficiency enhancement of devolution and privatization.

The, supposedly, effectiveness-enhancing potential of autonomous schools is seen as doubtful in some of the comments on Chubb and Moe's (1990) study in the USA (cf. Scheerens, 1995; Witte, 1990). Analyses of effectiveness-enhancing mechanisms should be part of further work re- 
garding the effectiveness enhancing potential of decentralization and deregulation. According to Scheerens (1995) "choice" can hardly be seen as a convincing candidate among such mechanisms, particularly at the level of elementary education and the first phase of secondary education (also see Hill, Rowe, \& Holmes-Smith, 1994).

Another line of critical review and analysis concerns what Weiler (1990) refers to as the "symbolic nature" of decentralization and deregulation policies. Weiler identifies several "political" motives to play lip-service to decentralization and deregulation: "anything that can make the state appear less centralized and monolithic and more attentive to internal variations of needs and conditions could well be seen as a potential source of added legitimacy". Such considerations would call for empirical investigation of decentralization "at grass-root level", that is how it works out at the school level, as compared to official policy statements, in future empirical investigations.

\section{REFERENCES}

Bacharach, S.B., Bamberger, P., Conley, S.C., \& Bauer, C. (1990). The dimensionality of decision participation in educational organizations: The value of a multi-domain evaluative approach. Educational Administration Quarterly, 26, 126-167.

Beaton, A.E. (1992). Measurement what students know and can do. In B.P.M. Creemers \& G.J. Reezigt (Eds.), Evaluation of educational effectiveness (pp. 75-86). Groningen: ICO-publication.

Bray, M. (1994). Centralization/decentralization and privatization/publicization: Conceptual issues and the need for more research. International Journal of Educational Research, 21, 817-824.

Chubb, J.E., \& Moe, T.M. (1990). Politics, markets and American schools. Washington, D.C.: Brookings Institute.

Crowson, R.L., \& Morris, V.C. (1985). Administrative control in large-city school systems: An investigation in Chicago. Educational Administration Quarterly, 21, 5170.

Crump, S. (1994). Public school choice: An international perspective. Paper presented to research seminar. London: Kings College.

Deem, R., \& Brehony, K.J. (1994). The school, the parent, the banker and the local politician: What can we learnfrom the English experience of involving lay people in the site-based management of schools? Paper presented at the Annual Meeting of the American Educational Research Association, New Orleans.

Evans, J., \& Lunt, I. (1995). New forms of partnership between schools and local education authorities in the UK for making provision for students with special educational needs. Paper presented at the Annual Meeting of the American Educational Research Association, San Francisco.

Gerwitz, S., Bowe, R., \& Ball, S. (1994). Choice, competition and equity: Lessons from research in the UK. Paper presented at the Annual Meeting of the American Educational Research Association, New Orleans. 
Hargreaves, D.H. (1991). Key-note address to the International Congress for School Effectiveness and Improvement. Cardiff.

Hill, P., Rowe, K.J., \& Holmes-Smith, Ph. (1994). Factors affecting students' educational progress: Multilevel modelling of educational effectiveness. Paper presented at the International Congress for School Effectiveness and Improvement, Leeuwarden, the Netherlands.

James, E. (1994). The public-private division of responsibility in education. International Journal of Educational Research, 21, 777-783

Leune, J.M.G. (1994). Onderwijskwaliteit en de autonomie van scholen [Quality of education and the autonomy of schools]. In B.P.M. Creemers (Ed.), Deregulering en de kwaliteit van het onderwijs. Groningen: RION.

Luyten, J.W., \& Snijders, T.A.B. (1995). Teacher effects and school effects: Teacher change and variation of student scores across grades. Paper presented at the International Congress for School Effectiveness and Improvement, Leeuwarden, the Netherlands.

Macpherson, R.J.S. (1995). Accountability research in education: Current developments. International Journal of Educational Research, 23, 473-567.

Mintzberg, H. (1979). The structuring of organizations. Englewood Cliffs, NJ: Prentice Hall.

OECD (1994). School: A matter of choice. Paris: OECD/CERI.

Riddell, A.R. (1993). The evidence on public/private educational trade-offs in developing countries. International Journal of Educational Development, 13, 373-386.

Rideout, W.M., \& Ural, I. (1993). Centralized and decentralized models of education: Comparative studies. Development Bank of Southern Africa. Centre for Policy Analysis.

Scheerens, J. (1993). Het onderwijsbeleid op z'n kop [Educational policy topsy turvy]. Enschede: Universiteit Twente.

Scheerens, J. (1995). Nuances in autonomie [Differentiation in autonomy]. Tijdschrift voor Onderwijsresearch, 20, 97-114.

Scheerens, J., Korevaar, G.J., \& Rijcke, F.J.M. de (1991). Onderwijsindicatoren in Engeland, oftewel de vele valkuilen van een evaluatie-georiënteerde beleidsvoering opnieuw geïllustreerd [Educational indicators in England, or the many pitfalls of evaluation-oriented policy making reillustrated]. Tijdschrift voor Onderwijsresearch, $21,221-227$.

Weiler, H.N. (1990). Comparative perspectives on educational decentralization: An exercise in contradiction? Educational Evaluation and Policy Analysis, 12, 433-448.

Winkler, D.R. (1989). Decentralisation in education: an economic perspective. Washington: The World Bank. Population and Human Resource Department.

Witte, J.F. (1990). Understanding high school achievement: After a decade of research, do we have any confident policy recommendation? Paper delivered at the 1990 Annual Meeting of the American Political Science Association, San Francisco. 